\title{
Comparison of Injuring Effects of Vesicant, Irritant, and Nonvesicant Anticancer Drugs on Endothelial Cells
}

\author{
Takaaki Yamada ${ }^{1}$, Nobuaki Egashira ${ }^{1} *$, Maiko Imuta ${ }^{1}$, Ayami Bando $^{1}$, Takahisa Yano ${ }^{1}$, Mami Saito $^{1}$, \\ and Ryozo Oishi ${ }^{1}$ \\ ${ }^{1}$ Department of Pharmacy, Kyushu University Hospital, 3-1-1 Maidashi, Higashi-ku, Fukuoka 812-8582, Japan
}

Received April 8, 2011; Accepted August 8, 2011

\begin{abstract}
Anticancer drugs are classified as vesicant, irritant, and nonvesicant drugs on the basis of frequency of their vascular disorder. In this study, we compared the injuring effects of three typical anticancer drugs of each class on porcine aorta endothelial cells (PAECs). The concentration inducing 50\% cell viability inhibition was lower in the order of vesicant, irritant, and nonvesicant drugs. These results suggest that injuring effects of anticancer drugs on PAECs may be relevant as an indicator of frequency of their vascular disorder, and that this experimental model may be useful for the study of vascular disorder.
\end{abstract}

Keywords: vascular disorder, anticancer drug, endothelial cell

Intravenous injection of anticancer drugs often causes vascular-related adverse reactions such as venous irritation, vascular pain, phlebitis, and necrotizing vasculitis. These vascular disorders limit the continuation of chemotherapy and deteriorate patient's quality of life. Anticancer drugs are classified as vesicant, irritant, and nonvesicant drugs based on the frequency of vascular disorder $(1,2)$. Vesicant drugs (anthracyclines, taxanes, and vinca alkaloids) are defined as agents that cause local tissue necrosis when they are extravasated. Irritant drugs (platinum agents, topoisomerase inhibitors, alkylating agents, and some antimetabolites) are defined as agents that cause inflammatory reactions without persistent tissue damage at the time. On the other hand, nonvesicant drugs (a part of antimetabolites and monoclonal antibodies) are agents that produce little local tissue necrosis or inflammation (3). The procedure of treatment for extravasation is indicated for each group.

Since vascular endothelial cells are first exposed to drugs administered intravascularly, the endothelial cell dysfunction may contribute to vascular disorders. In fact, the endothelial cell injury is implicated in the pathophysiology of several diseases (4). We have reported that the protease inhibitor gabexate mesilate and the vesicant drug vinorelbine, which often cause severe vascular in-

*Corresponding author. n-egashi@pharm.med.kyushu-u.ac.jp Published online in J-STAGE on September 7, 2011 (in advance) doi: 10.1254/jphs.11070SC jury, induce cell injury in porcine aorta endothelial cells (PAECs) (5-7). However, comparison of injuring effects of vesicant, irritant, and nonvesicant drugs on PAECs has not been studied. In this study, we selected three typical drugs from each class of anticancer drugs (vesicant: vinorelbine, epirubicin, and actinomycin D; irritant: 5-fluorouracil, cisplatin, and irinotecan; nonvesicant: cytarabine, methotrexate, and nimustine) and compared their injuring effects on PAECs.

Vinorelbine, epirubicin, actinomycin D, 5-fluorouracil, cytarabine, methotrexate, and nimustine were obtained from Wako Pure Chemicals (Osaka). Cisplatin and irinotecan were purchased from Sigma-Aldrich Co. (St. Louis, MO, USA).

PAECs were obtained from Dainippon Sumitomo Pharmaceutical Co., Ltd. (Osaka). Cells were maintained in Dulbecco's modified Eagle's medium (MP Biomedicals Inc., Irvine, CA, USA) supplemented with $10 \%$ fetal bovine serum, $100 \mathrm{U} / \mathrm{mL}$ penicillin, $100 \mu \mathrm{g} / \mathrm{mL}$ streptomycin, and $250 \mathrm{ng} / \mathrm{mL}$ amphotericin B (GIBCO BRL, Grand Island, $\mathrm{NY}, \mathrm{USA}$ ) at $37^{\circ} \mathrm{C}$ in $5 \% \mathrm{CO}_{2}-95 \%$ air.

PAECs were seeded at a density of $1.0 \times 10^{4}$ cells/well in 24-well plates (Nalge Nunc International, Rochester, NY, USA) and grown to subconfluence. Cell viability was assessed by measuring the mitochondrial activity that reduces 2-(2-methoxy-4-nitrophenyl)-3-(4-nitrophenyl)-5-(2,4-disulfophenyl)-2H-tetrazolium monosodium salt (WST-8) to formazan, as described previously (8). Briefly, after treatment with anticancer drugs for 24 
$\mathrm{h}$, the cells were then washed with PBS and incubated with WST-8 assay solution (Cell Counting Kit-8; Dojindo Lab., Kumamoto) for $1 \mathrm{~h}$ at $37^{\circ} \mathrm{C}$ in humidified air supplemented with $5 \% \mathrm{CO}_{2}$. The incubation medium was carefully withdrawn and transferred to 96-well flat-bottom plastic plates (Corning Inc., Corning, NY, USA). The amount of formed formazan was measured from the absorbance at $450 \mathrm{~nm}$ with a reference wavelength of $620 \mathrm{~nm}$ using a microplate reader (Immuno-Mini NJ-2300; Inter Medical, Tokyo).

Data were expressed as the mean \pm S.E.M. The data were analyzed by one-way analysis of variance (ANOVA) followed by the Dunnett test. Statistical significance was defined as $P<0.05$. The concentration inducing $50 \%$ cell viability inhibition ( $\mathrm{IC}_{50}$ values) was estimated by probit analysis.

As shown in Fig. 1, all anticancer drugs examined except for cytarabine decreased the cell viability dosedependency. Vesicant drugs vinorelbine, actinomycin D, and epirubicin showed significant decreases at concentrations of $\geq 10 \mathrm{nM}, \geq 100 \mathrm{nM}$, and $\geq 1 \mu \mathrm{M}$, respectively. Irritant drugs cisplatin, irinotecan, and 5-fluorouracil showed significant decreases at $\geq 3 \mu \mathrm{M}, \geq 3 \mu \mathrm{M}$, and $\geq 30 \mu \mathrm{M}$, respectively. Nonvesicant drugs methotrexate and nimustine showed significant decreases at $\geq 1 \mathrm{mM}$ and $\geq 3 \mathrm{mM}$, respectively.

As shown in Table 1, $\mathrm{IC}_{50}$ values of vesicant drugs vinorelbine, actinomycin $\mathrm{D}$, and epirubicin were 0.30 $\mu \mathrm{M}, 3.04 \mu \mathrm{M}$, and $6.11 \mu \mathrm{M}$, respectively. Those of irritant drugs cisplatin, irinotecan, and 5-fluorouracil were 28.96 $\mu \mathrm{M}, 70.53 \mu \mathrm{M}$, and $3.49 \mathrm{mM}$, respectively. On the other hand, that of the nonvesicant drug nimustine was 3.07 $\mathrm{mM}$, and those of methotrexate and cytarabine were more than $10 \mathrm{mM}$.

In this study, vesicant drugs vinorelbine, actinomycin $\mathrm{D}$, and epirubicin markedly induced the cell injury, whereas nonvesicant drugs methotrexate and nimustine induced the cell injury at high concentrations and the other nonvesicant drug cytarabine did not induce cell injury. Many clinical reports indicate that vinorelbine and epirubicin induce phlebitis with a high frequency of over $30 \%(9-13)$. On the other hand, there is no report about phlebitis induced by methotrexate, nimustine, or cytarabine. In addition, there is also no report about actinomycin D-induced phlebitis. Perhaps the reason for this may be because actinomycin D is usually used for the treatment of childhood cancer at a low dose of 0.015 $\mathrm{mg} / \mathrm{kg}$ (14). The dosage and administration procedure of anticancer drugs vary widely with the therapeutic regimens. Therefore, this makes it difficult to compare the
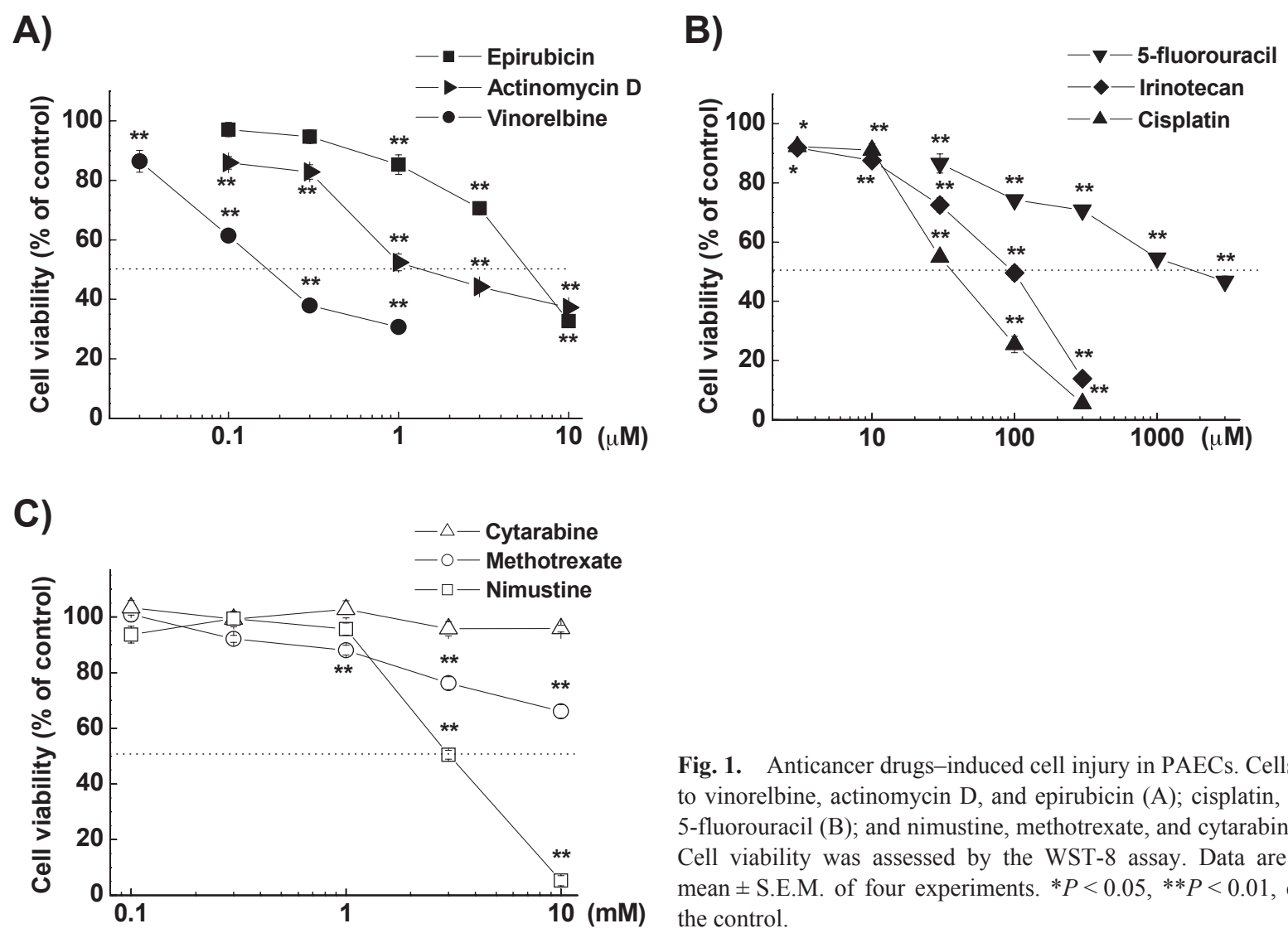

Fig. 1. Anticancer drugs-induced cell injury in PAECs. Cells were exposed to vinorelbine, actinomycin D, and epirubicin (A); cisplatin, irinotecan, and 5-fluorouracil (B); and nimustine, methotrexate, and cytarabine (C); for $24 \mathrm{~h}$. Cell viability was assessed by the WST- 8 assay. Data are expressed the mean \pm S.E.M. of four experiments. $* P<0.05$, ${ }^{* *} P<0.01$, compared with the control. 
Table 1. $\mathrm{IC}_{50}$ values of anticancer drugs in PAECs

\begin{tabular}{|c|c|c|c|}
\hline Classification & Drug & $\begin{array}{c}\mathrm{IC}_{50}[\mathrm{M}] \\
\left(\mathrm{IC}_{50}[\mathrm{w} / \mathrm{v}]\right)\end{array}$ & Typical dosage and administration procedure \\
\hline \multirow[t]{3}{*}{ Vesicant } & Vinorelbine & $\begin{array}{c}0.30 \pm 0.90 \mu \mathrm{M} \\
(0.33 \pm 0.10 \mu \mathrm{g} / \mathrm{mL})\end{array}$ & $25 \mathrm{mg} / \mathrm{m}^{2} / 50-100 \mathrm{~mL} / 5-10 \mathrm{~min}$ \\
\hline & Actinomycin D & $\begin{array}{c}3.04 \pm 0.27 \mu \mathrm{M} \\
(3.81 \pm 0.34 \mu \mathrm{g} / \mathrm{mL})\end{array}$ & $0.015 \mathrm{mg} / \mathrm{kg} / 5 \mathrm{~mL} / 5 \mathrm{~min}$ \\
\hline & Epirubicin & $\begin{array}{c}6.11 \pm 0.34 \mu \mathrm{M} \\
(3.55 \pm 0.20 \mu \mathrm{g} / \mathrm{mL})\end{array}$ & $60-100 \mathrm{mg} / \mathrm{m}^{2} / 50-100 \mathrm{~mL} / 5-10 \mathrm{~min}$ \\
\hline \multirow[t]{3}{*}{ Irritant } & Cisplatin & $\begin{array}{c}28.96 \pm 4.17 \mu \mathrm{M} \\
(8.69 \pm 1.25 \mu \mathrm{g} / \mathrm{mL})\end{array}$ & $60-80 \mathrm{mg} / \mathrm{m}^{2} / 500 \mathrm{~mL} / 120 \mathrm{~min}$ \\
\hline & Irinotecan & $\begin{array}{c}70.53 \pm 4.22 \mu \mathrm{M} \\
(43.95 \pm 2.63 \mu \mathrm{g} / \mathrm{mL})\end{array}$ & $180 \mathrm{mg} / \mathrm{m}^{2} / 250 \mathrm{~mL} / 120 \mathrm{~min}$ \\
\hline & 5-Fluorouracil & $\begin{array}{c}3.49 \pm 0.83 \mathrm{mM} \\
(0.45 \pm 0.11 \mathrm{mg} / \mathrm{mL})\end{array}$ & $400 \mathrm{mg} / \mathrm{m}^{2} / 50 \mathrm{~mL} / 5 \mathrm{~min}$ \\
\hline \multirow[t]{3}{*}{ Nonvesicant } & Nimustine & $\begin{array}{c}3.07 \pm 0.23 \mathrm{mM} \\
(0.95 \pm 0.07 \mathrm{mg} / \mathrm{mL})\end{array}$ & $70 \mathrm{mg} / \mathrm{m}^{2} / 100 \mathrm{~mL} / 30 \mathrm{~min}$ \\
\hline & Methotrexate & $\begin{array}{c}\geq 10 \mathrm{mM} \\
(\geq 4.54 \mathrm{mg} / \mathrm{mL})\end{array}$ & $3 \mathrm{~g} / \mathrm{m}^{2} / 500 \mathrm{~mL} / 180 \mathrm{~min}$ \\
\hline & Cytarabine & $\begin{array}{c}\geq 10 \mathrm{mM} \\
(\geq 2.43 \mathrm{mg} / \mathrm{mL})\end{array}$ & $2 \mathrm{~g} / \mathrm{m}^{2} / 500 \mathrm{~mL} / 180 \mathrm{~min}$ \\
\hline
\end{tabular}

injuring effects of anticancer drugs. In the right column of Table 1, the typical dosage and administration procedure of each anticancer drug are shown for the comparison of the injuring effects. It is unlikely that the vesicant drugs induce vascular disorders more easily than irritant and nonvesicant drugs because of higher concentration of injection per min. Although the concentrations of methotrexate and cytarabine per $\mathrm{mL}$ are relatively high, their $\mathrm{IC}_{50}$ values are more than $10 \mathrm{mM}$. In addition, $\mathrm{IC}_{50}$ values of nimustine were equivalent to those of 5-fluorouracil. However, nimustine showed a significant decrease in cell viability at more than the concentrations of $3 \mathrm{mM}$, whereas 5-fluorouracil showed that at more than the concentrations of $30 \mu \mathrm{M}$. Therefore, the frequency of vascular disorder induced by the drugs may be lower than that induced by other drugs. Taken together, these results indicate that the injuring effects of anticancer drugs on PAECs may be relevant as an indicator of frequency of their vascular disorder in the clinical setting. Since vascular endothelial cells are first exposed to drugs administered intravascularly, the endothelial cell dysfunction may contribute to vascular disorders.

In general, the vascular injury induced by intravenous drugs is related with high or low $\mathrm{pH}$ of infused fluid, osmotic pressure, and direct injuring effect. However, an infusion solution of anticancer drugs is usually at adjusted osmotic pressure. Additionally, epirubicin-induced phlebitis is not necessarily related with low $\mathrm{pH}$ of the infused fluid (9). Therefore, it is likely that anticancer drugs directly injure vascular vessels.

In our previous report (7), we indicated that vinorelbine increases intracellular reactive oxygen species production in PAECs and antioxidant agents such as glutathione and $\mathrm{N}$-acetylcysteine reverse the vinorelbineinduced decrease in cell viability, suggesting that oxidative stress plays an important role in the vinorelbineinduced endothelial cell injury. On the other hand, we found that glutathione and $N$-acetylcysteine had no effect on the vinorelbine-induced cell injury in HepG2 cells, human hepatoma cell lines (T. Yamada et al., unpublished data). Therefore, the injuring effects of anticancer drugs on PAECs may be related more closely to oxidative stress compared with their injuring effects on other cell types.

In conclusion, the study presented here demonstrates, for the first time, that the $\mathrm{IC}_{50}$ values of anticancer drugs on PAECs were lower in the order of vinorelbine, actinomycin D, epirubicin, cisplatin, irinotecan, nimustine, 5-fluorouracil, methotrexate, and cytarabine. Moreover, the other nonvesicant drug cytarabine did not induce the cell injury. These results suggest that the injuring effects of anticancer drugs on PAECs may become helpful as an indicator of frequency of their vascular disorder in the clinical setting. Therefore, the present experimental model using PAECs may be useful for the study of vascular disorders. In addition, it is important to consider clinical dosage and administration procedure of anticancer drugs. 


\section{Acknowledgment}

Part of this study was supported by a Grant-in-Aid for Scientific Research from the Ministry of Education, Culture, Sports, Science, and Technology of Japan (No. 19590146).

\section{References}

1 Dorr RT. Antidotes to vesicant chemotherapy extravasations. Blood Rev. 1990;4:41-60.

2 Sauerland C, Engelking C, Wickham R, Corbi D. Vesicant extravasation part I: Mechanisms, pathogenesis, and nursing care to reduce risk. Oncol Nurs Forum. 2006;33:1134-1141.

3 Ignoffo RJ, Friedman MA. Therapy of local toxicities caused by extravasation of cancer chemotherapeutic drugs. Cancer Treat Rev. 1980;7:17-27.

4 Tesfamariam B, DeFelice AF. Endothelial injury in the initiation and progression of vascular disorders. Vascul Pharmacol. 2007; 46:229-237.

5 Aki T, Egashira N, Hama M, Yamauchi Y, Yano T, Itoh Y, et al. Characteristics of gabexate mesilate-induced cell injury in porcine aorta endothelial cells. J Pharmacol Sci. 2008;106:415422.

6 Aki T, Egashira N, Yamauchi Y, Hama M, Yano T, Itoh Y, et al. Protective effects of amino acids against gabexate mesilate-induced cell injury in porcine aorta endothelial cells. J Pharmacol Sci. 2008;107:238-245.

7 Yamada T, Egashira N, Imuta M, Yano T, Yamauchi Y, Watanabe $\mathrm{H}$, et al. Role of oxidative stress in vinorelbine-induced vascular endothelial cell injury. Free Radic Biol Med. 2010;48:120-127.

8 Bai Y, Suzuki AK, Sagai M. The cytotoxic effects of diesel exhaust particles on human pulmonary artery endothelial cells in vitro: role of active oxygen species. Free Radic Biol Med. 2001;30:555-562.

9 Suga Y, Kumazaki M, Nishigami J, Takeda K, Kawagishi A, Ishizaki J, et al. [Improvement of epirubicin-induced phlebitis to switch from liquid preparation to lyophilized formulation]. Gan To Kagaku Ryoho. 2009;36:93-96. (text in Japanese with English abstract)

10 Vassilomanolakis M, Koumakis G, Barbounis V, Orphanos G, Efremidis A. Prevention of vinorelbine phlebitis with cimetidine. A two-step design study. Support Care Cancer. 2001;9:108-111.

11 Yoh K, Niho S, Goto K, Ohmatsu H, Kubota K, Kakinuma R, et al. High body mass index correlates with increased risk of venous irritation by vinorelbine infusion. Jpn J Clin Oncol. 2004;34:206-209.

12 Yoh K, Niho S, Goto K, Ohmatsu H, Kubota K, Kakinuma R, et al. Randomized trial of drip infusion versus bolus injection of vinorelbine for the control of local venous toxicity. Lung Cancer. 2007;55:337-341.

13 Sugimoto M, Matsui M, Harada M, Yamauchi Y, Moriyama N, Andou K, et al. Prevention of venous pain and phlebitis caused by epirubicin hydrochloride. Gan To Kagaku Ryoho. 2009;36: 969-974.

14 Cosmegen for injection (dactinomycin for injection) product information. In: Physicians' Desk Reference. 63th ed. Montvale: Physicians' Desk Reference Inc.; 2009. p. 2485-2488. 